\title{
Determining Optimum Point of Robusta Coffee Bean Roasting Process for Taste Consistency
}

\author{
Andi Dharmawan $^{1 *}$, Firstyoryza Cahyo ${ }^{1)}$, and Sukrisno Widyotomo ${ }^{1)}$ \\ 1)Pusat Penelitian Kopi dan Kakao Indonesia, Jalan PB Sudirman No 90, Jember, Indonesia \\ "Corresponding author: dharmawan_andi@ymail.com \\ Received: 6 November 2017 / Accepted: 21 January 2018
}

\begin{abstract}
Roasting is an important coffee bean processing that affect quality and flavor consistency. Roasting parameters are summarized in the roasting profile which describe density, water content, $\mathrm{pH}$, yield, taste, time and temperature as well as roasting technique of the beans. Roasting profile which is important for roaster master varies according to coffee bean types, such as Arabica and Robusta collected from specific area. Therefore, this paper studied the process of roasting Robusta coffee beans collected from Sumber Asin, Malang with normal roast technique using roaster machine in order to get taste consistency with determining optimum point from these parameters. During roasting process, temperature changes were recorded every two minutes for 20 minutes after temperature reached $180^{\circ} \mathrm{C}$. Density, moisture content, yield, $\mathrm{pH}$, and flavor were assessed after roasting. The normal roasting technique required optimum roasting time of 9-10 minutes at $180 \pm 5^{\circ} \mathrm{C}$, density value of $0.49 \pm 0.04 \mathrm{gram} / \mathrm{ml}$, water content of $3.5 \pm 1.3 \%$, losses $9.7 \pm 1.9 \%$, pH $5.3 \pm 0.2$, with chocolaty, spicy, and thick body flavors. There was strong correlation between Robusta roasting profile with all parameters measured. The optimal Robusta roasting time could be determined from intersection line between temperature and density in the roasting profile. Robusta optimum roasting time is about 10 minutes. The roaster master could use optimum roasting time in accordance to roasting quality.
\end{abstract}

Keywords: Roasting profile, Robusta, probat, flavor, optimum roasting time

\section{INTRODUCTION}

Roasting is one of important factors in coffee processing because it related with coffee flavor and aroma development. Studies have successfully identified 800 volatile compounds and out of that, 40 are major compounds in developing coffee aroma (Fabbri et al., 2011). Pyrolysis and maillard are two processes taking place while roasting due to degradation of reducing sugar, amino acids and chlorogenic acids (Wang, 2012).

Zollman (2012) classified roasting technique into slow, normal, and fast roasting.
Each roasting technique has its own specification and objective. Slow roast is roasting technique in which $50 \%$ heat declines right after turning point to decrease roasting time. It results in nutty, marshmallow, sweet and a little bit acidic tone but thin coffee. Although time-consuming, this technique can be use to get coffee bean with higher sweet tone.

Normal roast is roasting technique in which heat is used constantly; in other words, there is not any addition or reduction of heat in roasting drum. It results in coffee with well-balanced flavor, acidity and body. Fast roast is roasting technique where heat 
is increased to maximum level right after the turning point accelerating roasting process. It results in flat, herbal-like, low body, astringent (bitter), and medicinal coffee. As the result of this technique, surface of coffee beans seems burnt (Illey \& Viani, 2008).

Successful roasting produces coffee beans with optimum and consistent flavor (Illey \& Viani, 2008). Roasting is tricky and therefore, requires specific sets of skills to determine roasting profile of roaster and suitable roasting technique (Sutarsi et al., 2016). To facilitate roaster master, an analysis is conducted to describe normal roast profile into a graphic explaining correlation between different parameters of roasted coffee beans such as temperature, time, density, water level, $\mathrm{pH}$, yield, and flavor (Yusianto et al., 2007). Having studied this graphic, roaster master is able to decide characteristics or profile of the roasted coffee bean well and in consistent manner.

One type of roaster that is able to identify coffee bean profile is one made of stainless steel and layer of copper that is more longlasting. Roaster may have single drum or twin drum of which capacity is between $150 \mathrm{~g}$ and $50 \mathrm{~kg}$ per batch and uses LPG as source of heat. The drum spins between 50 and $60 \mathrm{rpm}$ (rotation per minute) to make sure they get roasted coffee bean with similar quality. The machine works by heating coffee bean when temperature of cylinder is $180^{\circ} \mathrm{C}$. It has tempering (cooling) rack and vacuum to prevent roasted coffee bean from getting additional heat (Pramita, 2009).

Nugroho et al. (2009) explained that roasting temperature and time affect physical and mechanical characteristics of Robusta coffee while Franca et al. (2009) state that color and weight loss depends upon roasting level. Therefore, an analysis to evaluate roasting process by analyzing characteristics of Robusta roasted coffee bean is needed to get consistent flavor. The objective of the study is to identify optimum point in Robusta coffee bean obtained from Sumber Asin, Malang, roasting process to get consistent flavor with normal roast technique using probat roaster.

\section{MATERIALS AND METHODS}

The material used in the study was Robusta coffee bean harvested from Sumber Asin Experimental Station, Malang, in 2017. The coffee bean specification matched SNI 2907-2008 (SNI, 2008) on coffee bean. Coffee bean was classified based on its type and roasting method. After that, the coffee bean was put in the oven under the temperature of $160^{\circ} \mathrm{C}$ for 16 hours to identify its preliminary water content. Three hundred grams of the sample was sieved with $6 \mathrm{~mm}$ mesh to identify coffee bean size and density. The following procedure was to classify physical quality of the coffee bean based on defective coffee bean value (Table 1). Roaster used in the study was cylindrical type roaster Probat Series BR72 (1996) of which capacity was $150 \mathrm{~g} / \mathrm{batch}$ and had 2 furnaces of which heat source was LPG. The setting of the study was in Coffee Flavor Testing Laboratory, Indonesian Coffee and Cocoa Research Center in Jember, where coffee flavor profilles were tested by 3 trained panelists. It lasted since July until September 2017.

The coffee beans were roasted using normal roast technique under minimum temperature of $180^{\circ} \mathrm{C}$ (Nugroho et al., 2009). Every two minutes until 20 minutes, coffee bean density, water content, $\mathrm{pH}$, and flavor based on the SCAA were observed (in SCAA, 2015). Three replications were applied for every observation. The data were analyzed using descriptive quantitative technique. Statistical analysis using Statistical Package for Social Sciences 16.00 was run for the analysis result. Spearman's correlation analysis was carried out to explain the correlationship 
between variables. The results of the analyses were formulated into scatter line representing characteristics and profiles of Robusta roasted coffee beans.

Table 1. General information regarding the Robusta coffee sample

\begin{tabular}{lc}
\hline Specification & Information \\
\hline Process method & Dry process \\
Moisture content & $12.00 \pm 0.05 \%$ \\
Physical quality & $\mathrm{I}(\mathrm{first}$ grade) \\
Bean dencity & $0.74 \pm 0.01 \mathrm{~g} / \mathrm{mL}$ \\
Bean size & Medium \\
\hline Note: The sample was analyzed based on SNI $2907: 2008$.
\end{tabular}

\section{RESULTS AND DISCUSSIONS}

Prior to roasting, a roaster master should sort coffee beans (green bean) using SNI 29072008 as the reference. The standard discussed physical quality of coffee beans such as identifying roasting method, maximum water content in coffee bean is $12.5 \%$, and quality I (defective coffee bean value should be lower than 11). The study used robusta coffee bean harvested in 2017. Table 1 described specification of the robusta coffee bean used in the study.

Identifying coffee bean specification will guarantee that coffee bean has similar quality prior to testing and analysis. Quality I refers to a category in which maximum defective coffee bean value is 11 . Defective coffee beans are ones that is black, has hole or breaks. Coffee bean size is observed using $6 \mathrm{~mm}$ mesh. Large coffee bean will not go through the mesh while small coffee bean will.

When normal roast was taking place, heat from roasting drum moved to the coffee bean (conduction and convection). Once coffee bean temperature reached $27^{\circ} \mathrm{C}$ (room temperature), the bean was placed into a drum of which temperature was $180^{\circ} \mathrm{C}$; at some point, both temperatures would reach certain point causing the drum temperature to decrease. It happened due to coffee bean evaporation. Evaporated water filled the entire drum reducing its temperature. This process is called charge temperature (De Wit 2009). Based on the observation, it took one minute and thirty seconds before temperature of the roasting drum decreased from $180^{\circ} \mathrm{C}$ to $135^{\circ} \mathrm{C}$ (equilibrium). The water content was $10.2 \pm 0.2 \%$ or decreasing $2 \%$ compared to one prior to roasting.

The drum (roaster) temperature gradually increased causing maillard or non-enzymatic browning producing complex compound with heavy molecule weight making green coffee bean brown or even black if the process lasts longer. During the process, amino acid functioned as catalyst reacted with reducing sugar compound affecting coffee bean thickness (body) and flavor (Nugroho et al., 2009). The process lasted for 6 minutes before the first crack due to reaction between resulting $\mathrm{CO}_{2}$ and evaporated water (Wiranata, 2016). This produced roasted coffee bean with nutty flavor and light brown (cinnamon) color or agtron 68 , which indicated that roasting time would finish between 1 and 2 minutes. Based on the observation, the first crack occurred after 8 minutes when temperature was between 170 and $180^{\circ} \mathrm{C}$. After the first crack, roaster temperature would keep increasing to $260^{\circ} \mathrm{C}$ after 20 minutes (Figure 1).

Density of the samples obtained between 2 minutes until minute 20 were analyzed. Density is a parameter used to identify to which degree a material is dense; it is represented by weight of a material per volume (Yusianto et al. 2005). It is important to measure coffee bean density to make sure there is no defect in the coffee bean (Wiranata, 2016). Wet coffee bean is categorized as defective one. Coffee bean softened due to different roasting temperature. Higher roasting temperature resulted in lower density. Based on the observation, there was different level of coffee bean (sample) density prior to and after roasting. 
The sample density tended to decrease. Prior to roasting, sample density was $0.74 \mathrm{~g} / \mathrm{mL}$ and after being roasted for 20 minutes, it declined to $0.18 \mathrm{~g} / \mathrm{mL}$, because water evaporates as the temperature increase. Development bean after the first crack occurred because compounds broke down due to excessive amount of heat making coffee bean expanding (Sutarsi et al., 2016). Figure 1 described these process in a more detail manner.

To get qualified and consistent roasted coffee bean, roaster should have specific roasting skills and knowledge on roasting profile. The Robusta coffee bean in the study had spicy, chocolaty flavor and thick body based on SCAA's standardized roasting test.
The intercept in Figure 1 showed roasting time was 10 minutes. Nugroho et al., (2009) argued that 10 minutes was the optimum roasting time to produce medium roasted coffee bean. In other words, the intercept is in line with previous study. As an addition, the intercept also showed other roasting profiles such as density of $0.49 \pm 0.04 \mathrm{~g} / \mathrm{mL}$, water content of $3.5 \pm 1.3 \%$, weight loss of $9.7 \pm 1.9 \%$, and $\mathrm{pH}$ of $5.3 \pm 0.2$.

Spearman's correlation analysis showed that there was strong correlation between roasting temperature and density $(99 \%$ level of confidence). There was also strong correlation between water content and yield while $\mathrm{pH}$ had strong correlation at $95 \%$ confidencial level (Table 2).

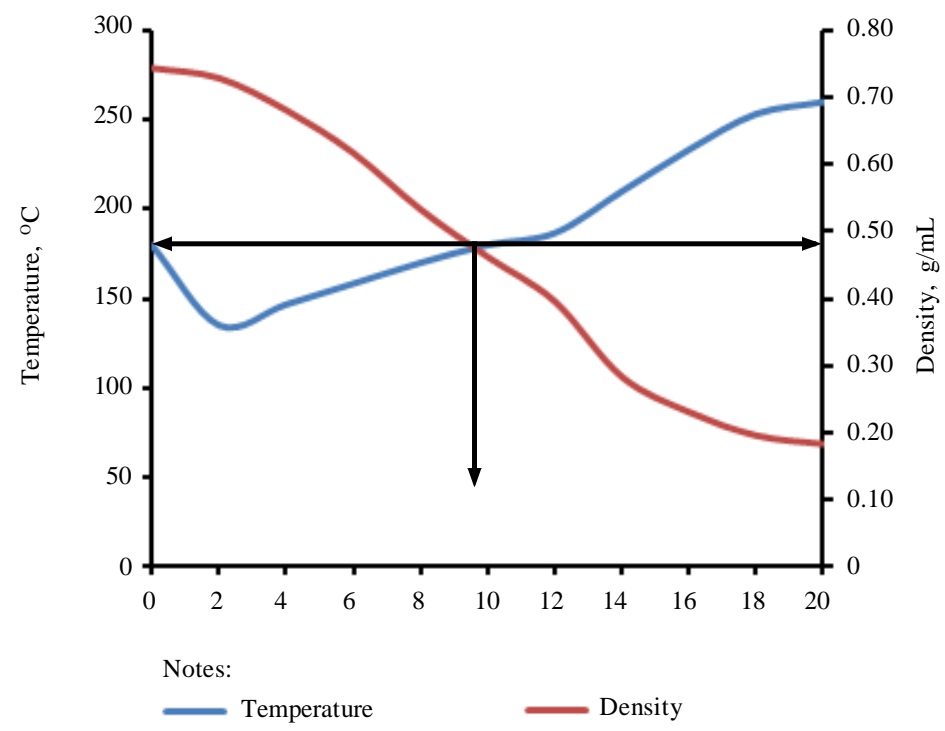

Figure 1. Development of roasting temperature and coffee bean density during roasting process and the intercept of both

Table 2. Spearman's corelation analysis result

\begin{tabular}{|c|c|c|c|c|c|c|}
\hline \multicolumn{7}{|c|}{ Spearman's Correlations $(\mathrm{N}=11)$} \\
\hline & Parameter & Temperature & Moisture content & Weight loss & Density & $\mathrm{pH}$ \\
\hline Time & Coef. & $0,888^{*}$ & $-1,000^{*}$ & $1,000^{*}$ & $-1,000^{*}$ & $0,636^{* *}$ \\
\hline & Sig. 2 tailed & 0,000 & & & & 0,035 \\
\hline
\end{tabular}

\footnotetext{
* Significant level $99 \%$.
}

** Significant leve 95\%. 
It is found that a parameter has strong relationship when correlation coefficient value is between 0.8 and 1 (Wiranata, 2016). Positive marking (+) showed direct proportion while negative marking (-) showed inverse proportion. Figure 1 show equilibrium at certain scale which was the major character in form of optimum roasting time. Based on the analysis, optimum roasting time was between 9 and 10 minutes, temperature was $180^{\circ} \mathrm{C}$, and density was between 0.45 and $0.50 \mathrm{~g} / \mathrm{mL}$ as shown in Figure 3 .

As an addition, the analysis showed similar phenomenon on the relationship between moisture content and weight loss. Equilibrium point (Figure 1) would show water content of roasted coffee bean by drawing imaginary line to line describing moisture content. Water content is one of the factors affecting yield because water is evaporated along with volatile gas compound (Edvan et al., 2016). Based on the analysis, moisture content at the equilibrium of both graphics was $3.5-4.0 \%$ and weight loss was $10-11 \%$. It happened because the coffee bean contained some amount of water. Moisture content was decreasing continuously due to high heating; Between minute 18 and 20 when temperature was $260^{\circ} \mathrm{C}$, carbon and oil compounds started evaporating making coffee bean surface shiny (Boot, 2005).

Figure 3 described $\mathrm{pH}$ or acidity that will influence coffee flavor. Roasting causes acid compounds to break increasing $\mathrm{pH}$ as hydrogen increased (Zollman, 2012). Based on the analysis, normal roasting would result in different acidity level; the lowest $\mathrm{pH}$ was 5.17 after 10 minutes (Figure 3). The SCAA (2015)'s standard stated that 7.75 is the highest or best average $\mathrm{pH}$ for coffee bean. Therefore, graph describing correlation between different variables will provide explanation on roasting characteristics and profiles. Intercept between the graphs in the study represents optimum condition for normal roast using probat. Optimum roasting, according to Sutarsi et al. (2016), is determined by physical and chemical characteristics of coffee bean such as water content and color at several different temperatures.

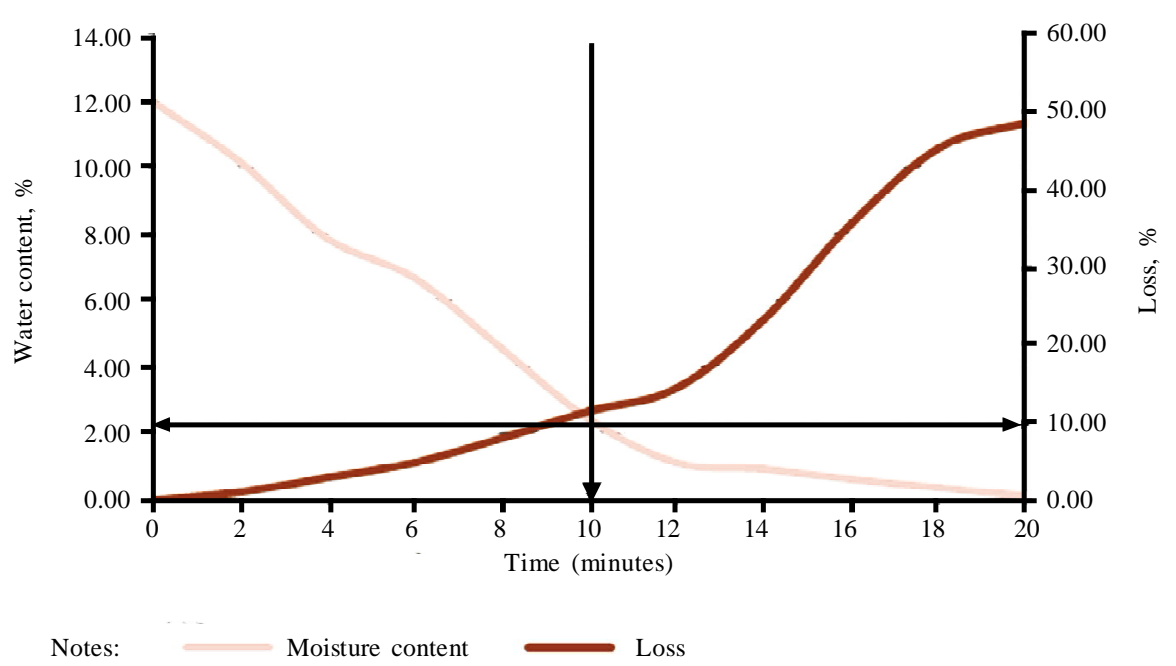

Figure 2. Intercept between moisture content and weight loss during coffee roasting 


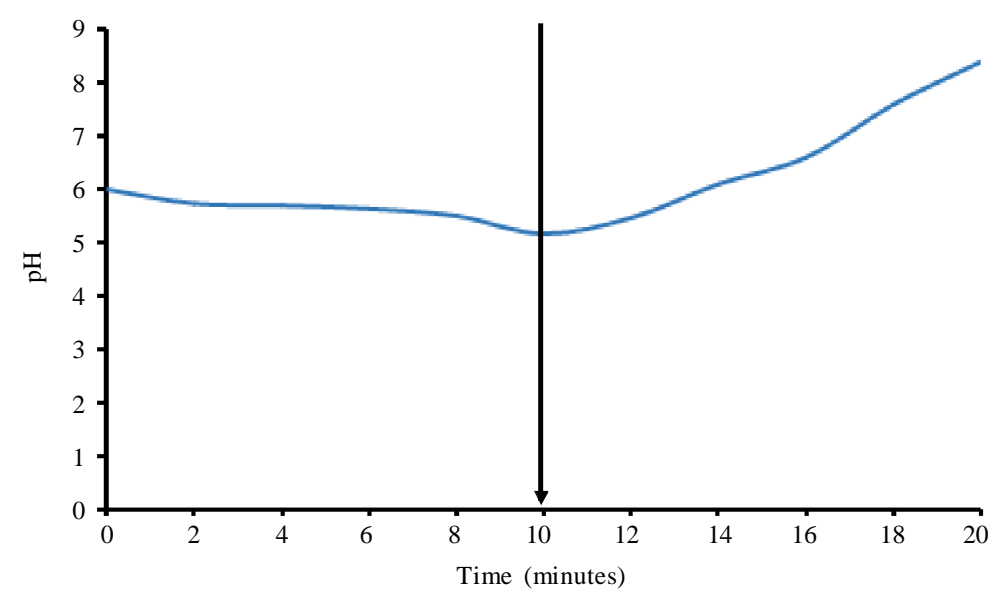

Figure 3. Change of acidity level value in each sample

\section{CONCLUSIONS}

Based on the findings, to roast Robusta coffee bean using normal roast, roasting time should be 10 minutes under temperature of $180 \pm 5^{\circ} \mathrm{C}$ at medium level. The density is $0.49 \pm 0.04 \mathrm{gram} / \mathrm{mL}$, water content is $3.5 \pm 1.3 \%$, weight loss is $9.7 \pm 1.9 \%$, and $\mathrm{pH}$ is $5.3 \pm 0.2$. The coffee bean has chocolaty, spicy flavor and thick body. These profiles facilitate roasting process of Robusta coffee to get coffee bean with good and consistent quality. A roaster master should understand the effect of temperature change and density towards roasting time, to develop suitable roasting technique.

\section{ACKNOWLEDGEMENT}

The researchers would like to thank Bayu Setyo Abdurrizal and Nofrian Prihandoko, technicians in Coffee Flavor Testing Laboratory and more importantly, to Director of Indonesian Coffee and Cocoa Research Institute that provides facilities and funding for the study.

\section{REFERENCES}

Boot, W.J. (2005). Reflections on roasting fundamentals. Roast Magazine, 1-4.

BSN (2008). SNI 01-2907-2008, Biji Kopi. Badan Standardisasi Nasional.

Edvan; B. Thomas; R. Edison \& M. Same (2016). Pengaruh Jenis dan Lama Penyangraian pada Mutu Kopi Robusta (Coffea canephora). Jurnal Agroindustri Perkebunan, 4, 31-40.

Fabbri, A.; C. Cevoli; L. Alessandrini \& S. Romani (2011). Numerical modeling of heat and mass transfer during coffee roasting process. Journal of Food Engineering, 105, 264-269.

Franca, A.S.; L.S. Oliveira; R.C.S. Oliveira; P.C.M. Agresti \& R. Augusti (2009). A preliminary evaluation of the effect of processing temperature on coffee roasting degree assessment. Journal of Food Engineering, 92, 345-352.

Illey, A \& R Viani. (2008). Revolution of Roaster. Elsevier Academic Press. $2^{\text {nd }}$ ed. Vol. 2. London, UK.

SNI (2008). Standard Nasional Biji Kopi. Badan Sertifikasi Nasional, Jakarta. 
Nugroho, J.; J. Lumbanbatu \& S. Rahayoe (2009). Pengaruh suhu dan lama penyangraian terhadap sifat fisikmekanis biji kopi Robusta. Teknik Produk Pertanian, 2, 17-25.

Pramita, M.R. (2009). Sanitasi Pabrik di PT. Podorejo Sukses Magelang, Jawa Tengah. Universitas Sebelas Maret Surakarta, Surakarta.

SCAA (2015). SCAA protocols cupping specialty coffee. Specialty Coffee Association of America.

Sutarsi, E.R. \& I. Taruna (2016). Penentuan tingkat sangrai kopi berdasarkan sifat fisik kimia menggunakan mesin penyangrai tipe rotari. Prosiding Seminar Nasional APTA, No. 2008, 306-12.

Wang, N. (2012). Physicochemical Changes of Coffee Beans During Roasting. University of Guelph, Canada.
Wiranata, R. (2016). Pengaruh tingkat penyangraian terhadap karakteristik fisik dan kimia kopi Robusta (Coffea canephora). Journal of Food Engineering, 33, 1-4.

Wit, J. De (2009). The Coffee Roast Process. Technische Universiteit Eindhoven.

Yusianto (2007). Mutu fisik dan cita rasa beberapa varietas kopi Arabika harapan pada beberapa periode penyimpanan, Pelita Perkebunan, 23, 205-230.

Yusianto; R. Hulupi; S. Mawardi \& C. Ismayadi (2005). Sifat fisiko-kimia dan cita rasa beberapa varietas kopi Arabika. Pelita Perkebunan, 21, 200-222.

Zollman, K. (2012). Roasting science: Looking closely at your curves. Roast Magazine, $5,80-87$.

$$
* * 0 * *
$$

